\section{HIV History}

\section{To the editor:}

I once found Peter Deusberg [sic]amusing. He seemed to be asking the reasoned rhetorical questions that people who needed questioning should have been asked. No more. Deusberg's questions have become assertions of his own ignorance and his latest attack on Stephen Edgington is more primitive than reasoned.

Let me recount some of the history surrounding the issues of HIV latency. In 1987 I examined lymphoid tissue removed from a patient with parotid enlargement and found that when the formaldehyde fixed tissue sections were digested with a protease to allow penetration of an HIV RNA probe for in situ hybridization, enormous amounts of viral signal could be found. Clearly the observed facts were in conflict with the dogma of the day (which said that only one of 100,000 cells were infected). This led to months of experiments to be sure that this was not artifact, the details of which I shall not relate. The case was published in $1989 .{ }^{1}$ I then began to search in earnest for lymphoid tissues from HIV infected individuals but encountered enormous obstacles from pathologists and clinicians in a number of institutions. Finally I confirmed my original findings in twelve lymphoid tissues using a variety of probes, protocols, and isotopes. The findings were that the "germinal" centers of lymph nodes contained enormous amounts of HIV RNA when the fixed tissues were digested with protease prior to hybridization. Before this report was submitted I accepted an invitation from Professor Paul Racz in Hamburg to visit his lab and to teach his personnel in situ hybridization. Professor Racz is one of the world's authorities on lymphoid tissues in HIV disease and has collected hundreds of specimens in all stages of the disease. In the Racz lab (where for the first time I had technical help) we confirmed my original findings in over a hundred specimens that are still being analyzed. While there, Heidi Schmidt, Andrea von Stamm, Klara Tenner-Racz, and I tried a number of other experiments. These collaborators tried hybridizing tissues without digestion in order to do immunostaining. When I looked at the slides it dawned on me that protease treatment revealed virus but that without protease the only signal from cells producing HIV mRNA. Coupled with the understanding I had gleaned from Paul Racz I returned to the U.S. and together we submitted a paper (reference 2, which I assume Deusberg still has not read). In my rush to publish, alas, Heidi Schmidt and Andrea von Stamm were not included in the final manuscript. The essence of the paper was reported at the Gallo lab meeting in the summer of ' 91 . Deusberg did not attend.

In the meanwhile Guiseppe Pantaleo and Cecelia Graziosi in Dr. Fauci's laboratory were applying PCR to confirm my in situ findings and Jan Orenstein was using the electron microscope to confirm the evidence of all of us as well as the other EM findings on protein encrypted virus in lymphoid tissue. We reported a theoretical account last year ${ }^{3}$, and another specific article has recently appeared in Nature (27 March 1993) showing the work of all of us. ${ }^{4}$

Duesberg has taken the accurate account of Edgington and attempted to use it to his own purposes. For example, the idea that viruses are always inacti- vated by antibodies. Functional virus inactivation by antibodies was disproved by the late Albert Sabin in 1935 in a series of brilliant papers. Antibodies are not enzymes. While virus may be enclosed in complement and globu-

lins, it is still virus as evidenced by the infection of hemophiliacs by Factor 8, cell free but with viruses from immunized donors.

What has emerged despite Deusberg is a simple explanation of HIV pathogenesis. Antibody-coated virus from semen or blood is deposited in tissues draining into the lymphatics. Tcells become productively infected and produce vinus on their surface. This virus immunizes and infects other T cells. With the appearance of antibodies most of the virus is removed from the circulation al though large amounts are retained in the germinal centers on the surface of follicular dendritic cells (FDC). This virus insidiously continues to infect other activated $T$ cells over years as they pilgrimage through the germinal centers. As the reserves of $\mathrm{T}$ cells or the equilibrium produced by $\mathrm{T}$ cells disappears, chaos in the lymph nodes begins and even the FDCs become productively infected. The death of $\mathrm{T}$ cells is compounded and AIDS defining illnesses appears with the rise in viremia. Death ensues. A tragic story that is true in principle if not details in all of the lentiviral diseases.

This means HIV disease is a histopathological disease. Sampling peripheral blood for HIV disease progression is at best like telling a woman with a lump in her breast that you want to draw blood from her arm until you find cancer cells instead of doing a biopsy. The implications for virus suppression therapy and for the vaccine industry are obvious. Give it up Duesberg! Give it up.

1. Tunkel, D.E., Loury, M.C., Fox, C.H., Goins, M.A., Johns, E. Bilateral parotid enlargement in HIV seropositive patients. Laryngoscope (1989) 99: 590-95.

2. Fox, C.H., Tenner-Racz, K., Racz, P., Firpo, A., et al. Lymphoid germinal centers are reservoirs of human immunodeficiency virus type 1 RNA. J. Infect. Dis. (1991) 164 (6): 1051-7.

3. Fox, C.H., and Cottler-Fox, M. The pathology of HIV infection. Immunology Today (1992) 13(9): 353-356.

4. Pantaleo, G., Graziosi, C., Demarst, J.F., Butini, L., Montroni, M., Fox, C.H., Orenstein, J.M., Kotler, D.P., and Fauci, A.S. HIV infections active and progressive in lymphoid tissue during the clinically latent stage of the disease. Nature (1993) March 27, in press.

Cecil H. Fox Molecular Histology Labs 7605-F Airpark Road Gaithersburg, Maryland 20879

Peter Duesberg replies:

Before I take your advice "Give it up Deusberg [sic]! Give it up." it would be useful to learn how to translate your "enormous amounts of HIV RNA" into absolute numbers. If this could be accomplished we could have a scientific discussion about the terms of my surrender.
FIGURE 1A.

Section of a lymph node from an HIVinfected individual. The tissue has been hybridized with an HIV antisense probe without enzymatic treatment. The tissue is photographed at low power in dark field. There are two protions of lymphoid germinal centers in view and two positive individual cells, probably, lymphocytes. (160 x)

\section{FIGURE 1B.}

Consecutive section of the same lymph node following protease digestion of the tissue but otherwise identical processing. The HIV RNA signal appears as silver grains that in this microscope image appear white. It has been estimated that each silver grain represents three virions. Electron micrographs contirm that the viral RNA is contained on the surface of the processes of follicular dendritic cells and not that the cells themselves are productively infected. (160 x) (Reprinted from reference 3.) 